University of Washington Tacoma

UW Tacoma Digital Commons

Urban Studies Publications

Urban Studies

4-29-2019

\title{
Public Housing Authorities in the Private Market
}

Rachel Garshick Kleit

Whitney Airgood-Obrycki

Anaid Yerena

University of Washington Tacoma, yerena@uw.edu

Follow this and additional works at: https://digitalcommons.tacoma.uw.edu/urban_pub

\section{Recommended Citation}

Kleit, Rachel Garshick; Airgood-Obrycki, Whitney; and Yerena, Anaid, "Public Housing Authorities in the Private Market" (2019). Urban Studies Publications. 133.

https://digitalcommons.tacoma.uw.edu/urban_pub/133

This Article is brought to you for free and open access by the Urban Studies at UW Tacoma Digital Commons. It has been accepted for inclusion in Urban Studies Publications by an authorized administrator of UW Tacoma Digital Commons. 


\title{
Public Housing Authorities in the Private Market
}

\author{
Rachel Garshick Kleit ${ }^{1^{* 2}}$ \\ Whitney Airgood-Obrycki ${ }^{3}$ \\ Anaid Yerena ${ }^{4}$ \\ Revision for Housing Policy Debate \\ Main text word count: 7680
}

*Corresponding author. Email: kleit.1@osu.edu

${ }^{2}$ City and Regional Planning, Knowlton School of Architecture, The Ohio State University, Columbus, OH USA

${ }^{3}$ Joint Center for Housing Studies, Harvard University, Cambridge, MA USA

${ }^{4}$ Urban Studies, University of Washington Tacoma, Tacoma, WA USA 


\section{Public Housing Authorities in the Private Market}

\section{Introduction}

Originally, U.S. public housing authorities (PHA) produced and managed publiclyowned, physical affordable housing units with mostly federal support. Today some are heavily engaged actively in the private housing market, using hybrid public and private strategies (Kleit and Page, 2015; Nguyen, Rohe, \& Cowan, 2012). To date, little is known about the extent to which PHAs augment their public housing and vouchers with other types of units and even less is known about the characteristics and environments of PHAs that own other units. Therefore, the goals of this paper are three-fold: to describe (1) which PHAs are likely to engage in a mix of public-private strategies, (2) how many such units PHAs have produced and (3) why their engagement with the private housing market varies around the county. These details are especially important given the increasing need for affordable housing in the context of declining federal resources since the 1980s and a policy environment that has pushed PHAs to work at the intersection of the public and private sectors. Thus, this study makes both an empirical and analytical contribution to the understanding of how PHAs provide affordable housing.

This paper outlines the policy context for PHAs, expected variations in organizational strategy as quasi-public ${ }^{1}$ entities, and the factors that might compel them to undertake publicprivate activities as a means for expanding their affordable housing stock. We hypothesize that small variations in their state legislative environment can facilitate increased private market activity. A national survey of PHAs points to a significant minority of PHAs engaging in housing ownership outside of the public housing stock. A content analysis of enabling legislation for 48 states and a multivariate analysis suggest that some state and local contexts can foster PHA's

\footnotetext{
${ }^{1}$ Quasi-public organizations are private corporations that have the backing of government.
} 
private-public strategies. Such an analysis offers insight into which contexts are conducive to PHAs successfully creating or preserving affordable units.

\section{The Policy Context for PHAs}

Federal resources for affordable housing have decreased since the 1980s, and policy has devolved to the local level. In turn, PHAs have altered their methods of housing and service delivery to include a mix of private and public strategies (Kleit and Page, 2015; Nguyen, Rohe, \& Cowan, 2012). In the 1980s, PHAs started managing tenant-based vouchers, which increased the scope of their activities and pushed them to interact with the private housing market. Policy changes since the 1990s have moved PHAs even closer to supporting affordable housing through market means, as public housing redevelopment through HOPE VI² (1992-2010), a focus on asset-based management, ${ }^{3}$ the implementation of mixed-finance ${ }^{4}$ in 1998's Quality Housing Work Responsibility Act (QHWRA), and an increased emphasis on developing affordable housing with the Low-Income Housing Tax Credit program have all required PHAs to use private market strategies to finance and manage their properties.

As a result, PHAs increasingly use public funding to leverage private investment, harnessing the potential of markets for the development, management, and maintenance of their properties (Landis and McClure, 2010). This funding strategy, in the context of reduced resources for public housing, has signaled a move away from publicly owned affordable housing. The most recent iteration of this shift is embodied in the Rental Assistance Demonstration

\footnotetext{
${ }^{2}$ HOPE stands for Housing Opportunities for People Everywhere.

${ }^{3}$ In the public housing program, PHAs traditionally engaged in centralized management of their entire housing portfolio, with a centralized waiting list, maintenance, and property management. In 1998, QWHRA mandated asset-based management, moving PHAs to site-based management of public housing--managing them in parallel to how privately-owned affordable management is managed. This means that public housing is managed as part of a portfolio of assets, with site-base waiting lists, maintenance, and property management.

${ }^{4}$ Mixed finance is the ability for public housing authorities to use public capital funds to leverage private investment in housing.
} 
(RAD), which is facilitating the transition of public housing to private ownership. RAD is the result of a progression of policies that have been privatizing affordable housing (Reid, 2017), using private dollars to rehabilitate and retain subsidies in public housing. Thus, changes in U.S. housing policy since the 1980s have promoted both the private ownership of affordable housing and the layering of varied sources of funding and governance to create affordable housing (Vale, 2017).

Some PHAs are expanding their housing stock beyond government supported public housing for the first time, while others have owned affordable housing outside of the U.S. Department of Housing and Urban Development (HUD) stock for many years using funds from a variety of local and state sources (see, for example, Bloom, 2008; Kleit and Page, 2008, 2015). This flexibility in unit ownership is possible because of PHAs' complex policy and legal environment. PHAs operate under federal regulation to expend federal funds but are statechartered, locally founded and controlled organizations. Changing mandates at federal, state, and local levels of government lead to great variation in how PHAs function, the types of housing and services they provide, and their local impact (Kleit and Page, 2008, 2015; Nguyen, et al., 2012; Quercia and Galster, 1997).

\section{PHAs as Public Organizations Responding to Ambiguous Policy Mandates}

Devolved and ambiguous policy mandates ask public housing authorities to engage the private market to build, renovate, or purchase affordable housing; the result is great variation in service delivery, that PHAs' internal organizational characteristics and external contexts shape. Ambiguity for public agencies, like PHAs, arises from two sources: (1) the multiple levels of government that signal policy direction (Cho, Kelleher, Wright, \& Yackee, 2005) and (2) 
legislation that contains "fuzzy terms"(Chun and Rainey, 2005, p. 3) without specificity in either the end objectives or the means for achieving those objectives (Moore, 1995).

Conflict occurs when a policy contains multiple mandates to achieve competing goals. For example, a PHA looking to refinance and renovate public housing using mixed finance may have multiple mandates that include attracting capital through investors who expect a profit while continuing to serve the poorest households who may not be able to pay sufficient rent to support a financial return. Ambiguity and conflict create uncertainty, and public organizations have to make decisions about priorities and courses of action (Cho, et al., 2005). Uncertainty can also hinder performance (Meyers, Riccucci, \& Lurie, 2001) and provide a flexible space for experimentation and innovation (Moore, 1995). Given the dynamics of policy ambiguity and conflict, outcomes vary. With new policy mandates, PHAs that innovate take on programs and responsibilities that diverge from long-term activities and expectations. Owning and developing rental housing outside of the traditional HUD-assisted stock is the form of innovation we examine in this paper, and whose numbers are typically unknown.

Figure 1 illustrates what we mean by "housing outside of the traditional HUD-assisted stock." The vertical axis represents the amount of Fair Market Rent (FMR $)^{5}$ landlords receive; those on the top row receive full FMR (or more) and landlords in the bottom row receive less than FMR. The horizontal axis depicts the public subsidy status; the left column includes programs that involve a government supply or demand side subsidy while those on the right operate without a public subsidy.

[Figure 1 ABOUT HERE]

\footnotetext{
${ }^{5}$ HUD sets the FMR for a given metropolitan housing market annually, usually at the $40^{\text {th }}$ percentile rent of the housing stock for a given size unit, although some flexibility exists in small market areas or expensive markets.
} 
Cells I, III, and IV contain affordable housing with and without public subsidy. Landlords in these three cells receive rents that could be above or below the FMT. Units in Cell 1 are at or above the FMR with government subsidies. Residents in these units pay a fraction of their incomes (usually $30 \%$ ), the subsidy comprises the rest of the rent up to the FMR, and the resident also pays the amount over the FMR. These programs include housing vouchers such as Housing Choice Vouchers (HCV, formerly Section 8) and some state and local programs. Cell III units are also subsidized, but the total rent the landlord receives is below FMR. These include public housing, HCV used in below-FMR units, affordable-unit-set-asides in the Low Income Housing Tax Credit Program (LIHTC) (Burge, 2011; Freddie Mac, 2018), ${ }^{6}$ and some state and local programs. Units in Cell IV are also below FMR, but not due to public subsidies; instead these are units at the low end of the market, often called "naturally occurring affordable housing." While some of this housing may be in sub-par conditions, some of it may simply be old, but well maintained. Lastly, Cell II contains market-rate rental units, with rents that are at or above FMR, and have no public subsidies.

While funding agencies count units in Cells I and III, no centralized, official counts of those in Cells II and IV exist, which is one of the motives for undertaking this research. In this paper, "hard units" refer to a physical housing unit that has a stable subsidy with a private or public owner. "Soft units" refer to housing units where the subsidy is unstable or moveable, such as the HCV program. Either could be in Cells I, III, or IV.

Public housing authorities have historically provided housing in Cell III. In the 1970s, many PHAs began managing housing in Cell I, and as they innovate, may now be creating housing in Cells I, III and IV. Sometimes they also develop housing in Cell II. The choice of

\footnotetext{
${ }^{6}$ The Low-Income Housing Tax Credit (LIHTC) is managed by the U.S. Department of the Treasury. It provides tax credits that are allocated by state housing finance agencies to housing development projects. It is the largest affordable housing construction program in the U.S., and has been in place since 1987.
} 
whether to develop new rental housing and the mix of public subsidies and rents reflects a response to conflicting and ambiguous policy mandates from various levels of government. The results may depend upon the organization's internal characteristics and the external state and local environments.

\section{Innovation, Hybridity, and External Pressures}

Whether PHAs engage in innovative ownership depends in part on their organizational characteristics. Hybridity — the adoption of activities or organizational forms that cross sectorsis one factor that can contribute to housing innovation. Hybrid organizations are mission-driven and have characteristics of public, nonprofit, and private sector organizations (Billis 2010, Hoffman and Badiane 2012, Nguyen et al. 2012, Smith and Skelcher 2014, Skelcher and Smith 2015).

Much of what we know about hybridity in housing entities comes from Europe, where social housing organizations have similarly begun to privatize ownership and depend more on market dynamics to provide housing (Czischke et al. 2012, Mullins et al. 2012). Czischke et al. (2012) argue that in Europe, social housing organizations are beginning to act like social enterprises. They conceptualize social enterprises as hybrid entities of varying legal forms that act in accordance to the competing interests of public, market, and community forces and values. This stance at the nexus of these rival interests causes them to take actions that may be entrepreneurial rather than "bureaucratic," (Czischke et al. 2012, 428) and "conflicts between principles are played out in organizational strategies and day-to-day decisions" (Czischke et al. 2012, 428).

While European social housing organizations are private entities and most authors discuss non-profit or third-sector organizations becoming hybrids (Billis 2010, Smith and 
Skelcher 2014), in the U.S. quasi-public PHAs are also becoming hybrids as they employ private sector methods and financing to meet their public missions (Nguyen et al. 2012). The underfunding of public housing has meant that PHAs can only create new housing opportunities when they essentially act as hybrid organizations, entrepreneurially seeking out new funding streams and modes of operation to support affordable housing. PHAs that embrace hybridity have a range of flexibility that enables them to interact with and utilize the private market, collaborate with and tap into the skills of a variety of organizations, rank priorities and goals, and access a larger range of resources (Kleit, Forthcoming; Nguyen, et al., 2012).

In addition to hybridity, other PHA characteristics can foster innovation. First, experience and resources within government organizations influence housing innovation at the state and local levels. For example, governments that have raised revenues and developed programs are more likely to implement innovative strategies in the future (Stegman and Holden, 1987). Second, organizations that have more experienced leaders and staff are more likely to produce innovative housing programs (Basolo and Scally, 2008). Higher executive pay may reflect the cost of such experience. Third, an abundance of slack resources, which includes an excess of financial capital and personnel, may allow for more innovative housing programs (Basolo and Scally, 2008) except concerning the establishment of trust funds (Scally, 2012).

External state and local environments can also exert pressure on PHAs and influence their activities. Among local housing organizations, external factors influencing housing innovation include public perception and opinion, local economic and social conditions, local political culture, party politics, and the presence of interest groups (Basolo and Scally, 2008; Yerena, 2015). State and local governments are more likely to implement innovative policies, such as housing trust funds (HTFs) and housing assistance programs, when there is a perceived 
affordable housing crisis (Aiken and Alford, 1970; Basolo and Scally, 2008; Scally, 2012;

Stegman and Holden, 1987). State and local governments that emphasize public-private partnerships have a more extensive history of housing policy innovation (Stegman and Holden, 1987). States and localities with liberal constituencies and politicians are more likely to employ innovative strategies (Aiken and Alford, 1970; Basolo and Scally, 2008; Mueller and Schwartz, 2008). Governments under the control of a single political party are more likely to innovate, especially when the executive and legislative branches of government are unified under the same party (Basolo and Scally, 2008). Places with politically involved residents also have a greater frequency of implementing innovative housing programs (Aiken and Alford, 1970).

Pressure from affordable housing advocacy groups can lead to greater housing innovation within a policy network because these co-operative arrangements lead to resource and information sharing (Provan and Milward, 2001). For example, New Jersey advocacy groups suggested many housing programs implemented in the state (Basolo and Scally, 2008). In another case in Phoenix, the network of affordable housing organizations including housing agencies and advocacy organizations led to more productive discussions with city officials on regulatory barriers to the production of affordable housing (Lucio and De la Cruz, 2012). In contrast, activity among homebuilder and real estate interest groups blocks innovation, especially inhibiting the establishment of HTFs (Connerly, 1993).

Finally, the rate of local or state growth affects the resources available for innovative programs. Because programs often use tax revenues as the primary funding stream, areas with greater growth are more likely to have the resources to implement housing programs (Connerly, 1993; Mueller and Schwartz, 2008; Scally, 2012). HTFs are more common in high-growth states, where development fees provide a steady, dedicated funding source. Without sufficient tax 
revenue and funding sources, state and local governments do not have adequate resources to promote housing innovations (Mueller and Schwartz, 2008). Examples include: Florida and Oregon with $\$ 7,658,020$ and $\$ 5,538,901$ in HTF funds, respectively (U.S. Department of Housing and Urban Development, 2018). Innovation is also more likely to occur in older and larger cities (Aiken and Alford, 1970).

\section{PHAs’ External Organizational Environment: State Enabling Legislation}

State enabling legislation, which provides the legal framework to create PHAs and delineates their powers, may be an additional factor within the environment shaping variation in PHA's housing production (Kleit and Page, 2015). Restrictions or flexibility in state enabling legislation can impact activity and innovation at the local level more generally (Reese and Malmer, 1994). Housing authorities are not entities of the federal government; local governments create them under state law.

According to our review of enabling legislation in the 48 contiguous United States, the legislation follows the same outline and contains the same content; small variations may create variations in strategy. All states have language authorizing basic PHA powers, including the ability to acquire, rent, and sell properties. Yet, differences between states exist; these include the ability to bond-finance housing, determine tenant selection preferences, prioritize geographic service areas, and form affiliate organizations. Such differences have created a range of PHA types and activities, which, in turn, influence their ability to produce affordable housing using hybrid methods. For example, most states allow PHAs to issue their own bonds. Iowa is an exception, with the municipality rather than the PHA issuing bonds ("Iowa Municipal Housing Projects," 2017). And while most states enable PHAs to engage in partnerships, Illinois specifies that PHAs can work with for-profit entities for the purpose of developing, redeveloping, or 
owning "low-income and mixed-income rental and for-sale housing as a partner or member of a partnership, limited liability company, or joint venture" ("Illinois Housing Authorities Act," 2008). In Oklahoma, PHAs must hold a public hearing before starting a project with more than 20 new housing units ("Oklahoma Public Health and Safety," 2017), potentially hindering housing production.

\section{Research Strategy and Data}

To describe PHAs' production of housing units (both affordable and not), we relied on a combination of results from a survey of PHA directors and publicly available data on PHAs' housing stock. Much organizational information is available from HUD. We supplemented HUD's organizational information with that from a wide variety of sources to operationalize the internal and external operating environments of PHAs. Using this combination of sources, we then examined potential sampling bias and developed zero-inflated negative binomial (ZINB) models to predict the number of units PHAs own outside the HUD public housing stock. The ZINB model accounts for the high proportion of PHAs that do not own any units outside of the public housing stock.

Survey of Public Housing Authority Directors

We surveyed all PHA directors listed in HUD's 2009-2012 Picture of Subsidized Households and the Public Housing Director's Association's (PHADA) membership list (acquired through an agreement with PHADA). We used Dillman's (2009) method for online surveys, sending an initial email invitation with follow-up reminders every two weeks. PHADA members also received an introductory email from the organization. The survey took place between December 2013 and May 2015. Out of 3,933 active PHAs, and we received responses 
from 1,059 for a response rate of $27 \%$. Please the Appendix for a detailed discussion of survey sampling.

\section{[Table 1 ABOUT HERE]}

Dependent Variable: Ownership Outside of the Public Housing Stock among PHAs

Using public information, we are able to characterize those PHAs who responded to the survey and those who did not. In profile, survey respondents had a more diverse HUD housing portfolio than those who did not respond (Table 1). Responding PHAs were more likely to manage vouchers (62 percent, compared to 51 percent for non-respondents) and more likely to own public housing units ( 86 percent, compared to 75 percent). A greater percentage of responding PHAs (48 percent) manage vouchers and own public housing simultaneously than non-respondents (32 percent). Owning public housing units and managing a diverse portfolio may be an indication of a PHA's experience and comfort with owning hard units; PHAs that already own hard units may be more likely to develop or redevelop. Notably, about 4 percent of all housing authorities do not manage vouchers or own public housing; these agencies were less likely to respond to the survey -6 percent of non-respondents neither managed vouchers nor owned public housing.

\section{[Table 2 ABOUT HERE]}

Research suggests that PHAs can be path dependent on previous practices, and the purchase or development of units represents a novel approach (Kleit and Page, 2008). Although developing units is likely a more innovative action than simply owning units, it is difficult to find out who developed the units. Furthermore, few PHAs act as their own developer, often taking ownership or management of turn-key properties. Some PHAs purchase and redevelop existing properties. To address housing need, a typical non-profit sector response is to hold units for the 
long run to maintain their affordability. For these reasons, we focus on the ownership of units outside of the Public Housing and Housing Choice Voucher (HCV) programs (Table 2).

Given the nature of the survey and the focus of the research, the sample over-represents PHAs who own housing outside of the HUD public housing stock. The NHPD, the only available data source for non-respondents, provides supplementary estimates of the number of units PHAs own. According to the survey and NHPD, 919 PHAs own units outside of the public housing program. A significantly higher proportion of respondents own such units. They own 111,655 of the total estimated 150,886 non-public housing hard units. Just under half (44 percent) of responding PHAs owned such units, compared to 16 percent of non-respondents. The responding PHA with the most hard-units outside of public housing owned 7,000 $(2,816$ among non-respondents). In our sample, 464 PHAs own such housing, with an average of 241 units. Thus, the NHPD vastly underestimates the number of units owned outside of public housing, likely because it documents units from a limited number of funding sources (Table 2). The survey data provide the best estimate for such units, but due to the nature of the data sources, the survey sample unsurprisingly contains a high proportion of PHAs that own or develop units.

The survey also provided a unique picture of PHAs' ownership and development practices. While these PHAs own about 111,655 units, they report having developed or redeveloped 126,651 housing units, either within or outside of the HUD stock using mixedfinance, federal programs like LIHTC, state or local funding. Approximately one-third of respondents reported owning units that currently have no subsidy of any kind, amounting to 45,520 unsubsidized units. Some PHAs have engaged in development since the 1930s under state or local programs, but the majority of our survey respondents first began developing units 
in the 1990s and 2000s, suggesting that changes in housing mandates that began in the 1990s are initiating new development processes at the local level.

Additionally, in the process of identifying the extent of the PHA universe, we discovered 168 PHAs that are not in HUD's on-line systems. These PHAs have never operated under HUD's jurisdiction. Instead, they are the product of state and local policies. Some of these PHAs have developed or acquired units through funding sources such as state housing programs.

[Table 3 ABOUT HERE]

\section{PHAs' internal organizational attributes}

We included four concepts related to internal organizational factors that may influence PHA's ownership of non-public housing units. First, as proxies for a PHA's internal capacity to own and manage physical housing units, we use PHA size (calculated based on the number of voucher and public housing units in their portfolios), executive director compensation, and a binary variable indicating whether their HUD-assisted portfolio includes public housing units. The executive compensation amount also serves as an indicator of staff professionalization, ability to attract strong leadership, and financial resources available.

Second, PHAs with a history of innovation may be more likely to develop housing units because these programs provide experience and are typically granted to high-performing agencies. Participation in these programs also suggests that the agency is open to new ideas. We operationalized an agency's history of innovation by flagging their involvement in any demonstration or federal grant for local improvements in housing programs. This measure captures whether a PHA participated in Moving to Work (MTW), Choice Neighborhoods, or the Empowerment Zones and Enterprise Communities Program (EZ/EC). 
Third, operating at a larger geographic level could allow PHAs to access more resources and work across political boundaries, ultimately providing greater capacity. The majority of PHAs operate at the municipal level, but some PHAs serve a county, region, multiple cities, or a combined city and county. Between 2005 and 2014, 207 housing authorities transferred units to another PHA. HUD's records for these unit transfers suggest that some PHAs are operating on an increasingly regional scale to maintain fiscal solvency and reduce administrative burdens. One example of this phenomenon is occurring in the Los Angeles area where five municipal PHAs have transferred their units to the Los Angeles County Housing Authority. We determined PHA scale based on survey responses and the PHA name. In this analysis, when concepts concern the local service area, we use these categories as the geographic bounds for those data.

Finally, measures of hybridity fostering organizational structures come from our Survey of Public Housing Authorities (PHA Survey), where each indicated if it has an affiliate or subsidiary organization that develops or owns housing as part of the PHA's mission. About 30\% of the PHA's in our sample have a subsidiary or affiliate organization that owns and/or develops housing on behalf of the PHA in fulfillment of its central mission (Table 3). We also asked if the PHA is an independent organization, meaning that it is not integrated with local or county government. About $15 \%$ of PHAs in our sample are not stand-alone agencies but function as a part of a government agency, such as a city or county housing and community development division (Table 3). The Housing Authority of the City of Keyser in West Virginia is one example of an integrated agency. The presence of an affiliate suggests that the agency has a hybrid structure while integration with local government suggests that a PHA operates with added powers of local government (Kleit, Forthcoming; Nguyen, et al., 2012). Alternatively, integration with local government could mean more oversight and less market activity. 
[Table 4 ABOUT HERE]

Enabling Legislation as an External Environmental Factor

One of our key interests is whether enabling legislation plays a role in the activities of PHAs because it provides the basic framework of powers and limitations in which PHAs operate. Content coding the state enabling legislation for the 48 continental U.S. states (Kleit, Forthcoming) allows us to identify nine elements of enabling legislation that corresponded with factors discussed in the organizational theory and housing innovation literature. These elements capture the policy constraints and flexibility that can influence a PHA's organizational stance (Table 4). The coding is binary and denotes whether the legislation explicitly grants a given power. For example, the legislation contains information about PHAs' organizational structures and powers. It also defines the target population that the PHA may house (e.g., low-income population or percentage requirement for a range of income categories). Some states allow PHAs to cooperate with for-profit and non-profit organizations, form regional or county housing authorities, and utilize special development powers. Housing projects can sometimes include community or commercial facilities. PHA commissioners in some states can be compensated or simultaneously serve as an elected official of the county or municipality. These differences in state legislation can provide the tools and flexibility for innovative development. Most states allow county and regional PHAs to develop projects that include community facilities, the appointment of commissioners by a mayor or executive of a governing body, and the origination of bonds for sale.

[Table 5 ABOUT HERE]

Other External Environmental Factors Influencing PHA Activities 
We operationalize other external factors that the organizational literature suggests might influence PHA activities and innovation. The factors correspond to state or local levels of government (Table 5).

A more liberal or progressive political climate may be conducive to housing innovation (Aiken and Alford, 1970; Basolo and Scally, 2008; Mueller and Schwartz, 2008). First, at the state level, Gallup's (2013) State of the States results are the basis for the conservative advantage score. This score is the difference in the percentage of people identifying as Republican or leaning Republican and the percentage who identify as Democrat or leaning Democratic; a negative conservative advantage score indicates that the state is primarily Democratic. Second, Sharp's (2005) Unconventional Political Climate Index measures the local political climate. The index includes the number of women in the work force, adults with a college or graduate education, same-sex couples, unmarried families with children, adults engaged in skilled occupations, and households reporting religious adherence. The data come from the 2010 fiveyear American Community Survey Estimates (U.S. Census Bureau, 2010) as well as the 2010 Religious Congregations and Membership Study (Association of Statisticians of American Religious Bodies, 2010). The indicators are converted to z-scores and then summed into an index. A higher index score represents a more progressive political climate. A third element of the political climate is the degree of governmental fragmentation for the jurisdiction in which the PHA functions. More jurisdictions within a service area represent greater government bureaucracy, a potential requirement for coordination across municipalities, and the potential to have to make payments in lieu of taxes to a greater number of governments. Thus, we include the number of incorporated jurisdictions, taken from the U.S. Census' Tiger/Line files (2010 
Tiger/Line shapefiles (machine-readable datafiles), 2010), contained within the PHA's service area.

The presence of local and state housing assistance programs may suggest an environment that supports innovation in housing production programs (Connerly, 1993; Mueller and Schwartz, 2008; Scally, 2012; Stegman and Holden, 1987). Using the National Low Income Housing Coalition's (NLIHC) database of rental housing programs (National Low Income Housing Coalition, 2015), we use the count of capital and housing production funding and tenant-based rental assistance programs at the state level and a binary variable for local jurisdictions with an assistance program (they were rare, so a count did not make sense). At the time of analysis, there were 173 active capital and production programs and 163 rental assistance programs at the state or local level. A separate measure is an indicator of whether the state HTF has a dedicated funding source. This measure is based upon the Center for Community Change's (2013) database of state HTFs.

Advocacy may also increase the probability of innovation (Basolo and Scally, 2008; Lucio and De la Cruz, 2012; Provan and Milward, 2001). At the state level, we measured affordable housing advocacy as the count of how many NLIHC advocacy partners were in a state. At the local level, we used an advocacy organization (AO) index for housing organizations (Yerena, 2015). The AO index uses data from the National Center for Charitable Statistic's 2008 Business Master File (National Center for Charitable Statistics, No Date), using IRS information on all 501(c)(3) and (4) organizations categorized under the L-housing and shelter sub-group. From this dataset we obtained two variables: 1) a financial strength index and 2) mean age of AOs in the MSA. Following Yerena (2015), we created the financial strength index using Principal Components Analysis (PCA); the index is thus composed of the sum of the weighted z- 
scores of the total income, assets and number of organizations in the local service area. A high index score therefore reflects a greater potential for local affordable housing advocacy organizations to fill housing needs within a PHA's housing market.

Having a stronger tax base and a stronger housing market may influence the propensity for housing production and innovation (Stegman and Holden, 1987), both of which we represent with the number of housing units built from 2000-2010 and the percent growth in housing units from 1970-2010 at the state and local levels, using data from Geolytics (No Date). We include an interaction term for these variables, as PHAs may be influenced by a combination of both past and current trends. We also include the property tax per capita (in thousands of dollars) for the PHA service area, calculated from Data-Planet Statistical Datasets (2012). Second, states with more resources are more likely to have a state HTF with a dedicated source (Connerly, 1993; Mueller and Schwartz, 2008; Scally, 2012), included among measures of support for innovation.

Public perception, opinion and involvement may also influence innovation (Basolo and Scally, 2008). We measured state-level public involvement through voter turnout in 2012 (U.S. Elections Project, 2012).

More housing may be produced if there is a perceived housing crisis (Aiken and Alford, 1970; Basolo and Scally, 2008; Scally, 2012; Stegman and Holden, 1987). In this work, we indicate the housing crisis as housing problems, including cost burden, incomplete facilities, or overcrowding in 2012. A household is housing cost burdened if more than $30 \%$ of its income is dedicated to housing expenses. Incomplete facilities indicate that the housing unit lacks a kitchen or adequate plumbing. The Comprehensive Housing Affordability Strategy (CHAS) data (U.S. Department of Housing and Urban Development, 2011) include Census and American Community Survey (ACS) tabulations to identify housing problems. CHAS data shows the 
number of very low-income households that experience the three housing problems. Places with greater proportions of housing problems likely have a shortage of decent, affordable housing.

Additionally, to control for other influences, we included local jurisdictional characteristics, including the year the jurisdiction was founded ("Columbia Gazetteer of the World Online," 2014), segregation measures, racial composition, and average household income (Geolytics, No Date). We include percentage point change variables for the last three variables to capture the dynamic nature of local environments. We include interaction terms of the static and dynamic variable for each control. We also include regional fixed effects with indicators of HUD Regions to address any other omitted regional factors.

\section{Modeling}

To model the number of physical non-public housing units that each PHA owns, we used zero-inflated negative binomial (ZINB) models. The ZINB model estimates two parts simultaneously: a logit and a negative binomial regression. The logit predicts the occurrence of excess zeroes while the negative binomial predicts the number of non-public housing units that a PHA owns. This model was appropriate for the data because there is a high percentage of zeroes in the outcome variable (Hilbe, 2011); only 44 percent of our survey sample indicated that they owned non-public housing units. Additionally, we found that negative binomial modeling was appropriate for the count portion. We first modeled the count data using Poisson regression. However, the Cameron-Trivedi test for dispersion (Cameron and Trivedi, 1990) indicated that the data were overdispersed ( $z=3.6, p$-value $=0.00$ for Model 4$)$, violating the assumptions of the Poisson distribution. The negative binomial count model accounts for this overdispersion.

[Table 6 ABOUT HERE] 
Due to the iterative nature of our data collection, our sample potentially exhibits selection bias. To assess the impact of sampling bias on our modeling, we used PHA characteristics to develop inverse probability weights of responding to the survey. We compared weighted and unweighted models, considering the significance levels of variables, the directions of coefficient signs, the percent of cases accurately predicted, and model fit. Based on these parameters, we concluded that the weighted and unweighted samples produced similar results. Thus, the sample is fairly representative of the PHA universe, and the unweighted models provide better predictions of unit ownership. We therefore proceeded with unweighted ZINB models.

Our three models start with a constrained model (Model 1) that predicts the number of non-federal public housing units with internal organizational characteristics, the external operating environment for PHAs, and state fixed effects. We then omit state fixed effects and add state-level variables of interest (Model 2). The next model incorporates elements of the state enabling legislation to the model (Model 3) to see how legislation influences the number of units owned. Finally, to account for elements of the environment for which we cannot control, we then add fixed effects representing the HUD region for each PHA (Model 4). We use robust standard errors for each model to account for clustering at the state level and the Akaike information criterion (AIC) (Akaike, 1974) to compare the fit of the models with the lowest AIC representing the best fitting model.

\section{Results}

The survey results on their own suggest that PHAs are producing a substantial number of units outside of the traditional public housing stock, which is a meaningful contribution to affordable housing production amidst a resource-poor federal policy environment. The units 
PHAs develop ensure the continued existence of affordable, hard housing units while enabling PHAs to serve varied populations and meet locally specific housing needs.

Multivariate models offer evidence of why PHAs may own other housing, and why they may produce the quantities they do. The ZINB models highlight factors that influence these innovative responses. The logistic portion of the ZINB model identifies significant predictors of whether a PHA owns non-public housing units (Table 6). This portion of the model predicts excess zeroes, so negative coefficients are related to a higher probability of owning non-public housing units. The count portion indicates how each variable impacts the number of units a PHA owns (Table 7).

[Table 6 ABOUT HERE]

Organizational attributes influence both the probability of owning other units as well as how many. PHAs that are independent of local government offices are significantly more likely to own units outside of the traditional stock (Table 6). Integration with local government could indicate political oversight and control that stifles innovation or creative thinking about housing provision. Larger PHAs and those that also own public housing are more likely to own units outside of the traditional stock, suggesting that these PHAs have organizational capacity and experience with managing physical units. Larger PHAs also own more units (Table 7), which again is likely a function of the increased capacity and budgets that these organizations have. The interaction term between PHAs that have no public housing in their portfolio and PHA size is also significant in the logit portion of all models. When PHAs have public housing and are larger, they are more likely to own units. Though PHAs that own units outside of public housing tend to have affiliate organizations, the variable is not significant when controlling for PHA size and portfolio composition in any of the models. Similarly, most PHAs in our sample that have previous experience with demonstration programs own units outside of public housing, but this 
variable was not a significant predictor of housing ownership when controlling for other organizational characteristics.

\section{[TABLE 7 ABOUT HERE]}

The environmental attributes do not predict whether a PHA owns housing units outside of the traditional subsidized stock (Table 6) but are associated with how many such units a PHA owns (Table 7). PHAs that operate in local service areas with a higher unconventional political climate score own more units on average; the political climate score operationalizes a more progressive area. Responding to local housing needs, PHAs in places that have a higher share of very low-income renters living in overcrowded conditions also own more units. Additionally, PHAs appear to respond to demographic changes and the level of segregation in their service area. Service areas that are becoming more racially diverse with increasing shares of black residents from 1990-2010 are associated with PHAs owning more units. The interaction term between black population change and the share of black residents in 2010 is also significant in two of the four models, indicating that higher shares of black residents in 2010 slightly decreases the positive effect of black population change on unit ownership. PHAs in places with blackwhite segregation and with increasing Hispanic-white dissimilarity index scores are associated with greater unit ownership. The interaction term for the Hispanic-white dissimilarity variable is significant and negative; higher Hispanic-white dissimilarity reduces the effect of increasing segregation on unit ownership.

At the state level, none of the variables is consistently significant across all models and only one has significance in any model. In Model 4, which is the best fitting model, PHAs located in states with a trust fund that has a dedicated funding source have higher unit ownership. 
State trust funds provide valuable financial support for affordable housing development and may be a crucial source of gap financing for housing authorities.

State enabling legislation results suggest constraints and flexibilities that can lead PHAs to produce other units. In Model 4, states that allow consolidated PHAs are associated with a significantly higher likelihood of owning units outside of the public housing stock. PHAs that join together either organizationally or for certain projects may be increasing their capacity and tapping into a larger pool of resources. Additionally, when the jurisdictional governing body issues bonds on behalf of the PHA, PHAs are more likely to own units outside of the public housing stock. While this is counterintuitive, an entity of local government may be more successful at raising bond financing than a housing authority. However, the governing body issuing bonds is associated with lower unit counts. In states where PHAs are allowed to serve higher-income residents and prioritize serving elderly households, PHAs are also more likely to own units, though this effect is only significant in Model 3.

The ability to create or work with an affiliate organization is positively related with a higher number of units owned, though the result is insignificant. When the subsidiary can be for profit, PHAs own less housing on average (Table 7). The reason for this relationship is unclear, but it may be that ownership of housing developed with a for-profit entity transfers to another organization and is not included in the dependent count variable. It may also be that the partnership only produces housing when profit is made; it is notoriously difficult to produce housing affordability and take profits, thus limiting the production of units. The results indicate that the state enabling legislation can influence local PHA operations, although perhaps differently than we anticipated. 
In sum, the multivariate models suggest that PHAs' organizational attributes may predict whether they own other units, but their legislative and political environments influence how many. Many of the theoretically proposed variables do not have a significant impact on the odds of owning non-federal public housing units. However, integration with local government and state and local environmental variables are consistently significant. When PHAs operate in a progressive environment and as independent organizations, they may have greater support for affordable housing creation. Larger PHAs, which tend to have larger staffs and budgets, have greater capacity for owning and producing a diverse housing stock. The external policy environment influences hybrid activities, exhibited in the ability to create an affiliate organization or the ability to bond finance without jurisdictional approval, thus enabling PHAs to undertake affordable housing ownership and development. PHAs with these abilities can access more resources, employ a variety of strategies, and act outside the bounds of local political oversight. Enabling legislation, in part, controls factors that influence hybridity. Thus, the devolved policy environment and state-level enabling legislation influence how PHAs plan for housing at the local level.

\section{Conclusions and Implications}

This research lends new insight into PHAs as local actors operating within a complex policy environment that expects them to employ both public and private sector behaviors to meet their missions in a context of increasing need for affordable housing. We estimate that PHAs own more than 150,000 units of housing outside of the traditional HUD-assisted stock, and as policy continues on its current path, this resource could grow. However, state and local environments influence what PHAs do to meet local housing needs. To enable PHAs to effectively plan for housing, states and local governments should allow PHAs to form affiliate 
organizations, remove obstructive political oversight, and keep them separate from local government structures. These actions may require amendments to state enabling legislation. Local governments and PHAs should also be mindful of the racial composition of their service areas and actively work to maintain fair housing opportunities. Finally, state and local production programs could more effectively support PHAs and provide the resources needed to acquire and maintain affordable housing, taking advantage of their relative flexibility. At the same time, it is important to recognize that the sample represents those PHAs who are successfully developing housing, which our sample over-represents. Less successful PHAs may need other sorts of supports.

Modeling has its limits; some factors influencing PHA ownership are likely not included in our framework. PHAs face many unique challenges and local variations that the current literature does not reflect. Historical relationships and local politics likely play a large role in their behavior. Additionally, the data from the survey may be biased because PHAs that own and develop units may be more likely to want to share their innovations by responding. Thus, the results may be more generalizable to PHAs that engage in these activities, rather than all PHAs, though sample weighting procedures suggest this is a minimal concern.

Future research should focus on more in-depth case studies that examine how PHAs develop or acquire units, why they undertake these activities, and what they do with the additional units. The case studies will provide a nuanced understanding of the organizational attributes and resources needed to support PHAs as hybrid deliverers of housing services. Such information will also suggest a more nuanced typology of possible hybrid activities that PHAs can employ and their impact on organizational capacity. 
Public and hybrid service delivery are only as good as the people and institutions implementing them; it is possible to have effective or ineffectual public or hybrid service delivery. This paper is an important prelude to work that looks at the relative effectiveness of hybrid versus public service delivery. We also still need to know the prevalence of the adoption of hybridization. Finally, future research should assess whether hybridization produces a marketdriven approach that that fails to provide housing to the poorest of the poor. Alternatively, hybridization may provide for the experience to successfully use RAD-- a public-private mix of resources in an effort to retain and refurbish hard units of assisted housing. It may be that PHAs with a history of hybrid activities are more successful at using RAD.

While HUD programs provide housing opportunities for many low-income households, only a quarter of those who qualify for subsidies actually get them. PHAs with affordable housing that is subsidized through different programs or is completely unsubsidized may have greater flexibility in whom they serve and how they manage their communities. With unsubsidized housing units, PHAs can serve a diversity of income groups and foster mixed income communities. Additionally, PHAs with other units may be able to provide a housing ladder for lower-income residents or offer units at the FMR to voucher holders. As residents exceed the maximum allowable income for public housing, they could move to units within the PHA's stock, helping subsidized renters for an additional period before they enter the private rental market. Thus, housing units outside of the public housing stock have the potential to provide greater affordable opportunities for a variety of households. 


\section{References}

2010 Tiger/Line shapefiles (machine-readable datafiles). (2010). [Data set]. Retrieved December 17, 2014, from https:/www.census.gov/geo/maps-data/data/tiger-line.html

Aiken, M., \& Alford, R. R. (1970). Community structure and innovation: The case of urban renewal. American Sociological Review, 35(4), pp. 650-665.

Akaike, H. (1974). A new look at the statistical model identification. IEEE Transactions on Automatic Control, AC-19(6), pp. 716-723.

Association of Statisticians of American Religious Bodies. (2010). U.S. Religion Census [Data set]. Retrieved from http://www.rcms2010.org/index.php

Basolo, V., \& Scally, C. P. (2008). State innovations in affordable housing policy: Lessons from California and New Jersey. Housing Policy Debate, 19(4), pp. 741-774.

Bloom, N. D. (2008). Public Housing That Worked: New York in the Twentieth Century Philadelphia, PA: University of Pennsylvania Press.

Burge, G. S. (2011). Do Tenants Capture the Benefits from the Low-Income Housing Tax Credit Program? Real Estate Economics, 39(1), pp. 71-96. doi:10.1111/j.15406229.2010.00287.x Retrieved from $<$ Go to ISI $>$ ://WOS:000286739900004

Cameron, A. C., \& Trivedi, P. K. (1990). Regression-based tests for overdispersion in the poisson models. Journal of Econometrics, 46(3), pp. 347-364.

Center for Community Change. (2013). State housing trust funds. Retrieved Date Accessed, 2014 from https://housingtrustfundproject.org/housing-trust-funds/state-housing-trustfunds/.

Cho, C.-L., Kelleher, C., Wright, D. S., \& Yackee, S. W. (2005). Translating national policy objectives into local achievements across planes of governance and among multiple 
actors: Second-order devolution and welfare reform implementation. Journal of Public Administration Research and Theory, 15(1), pp. 31-54.

Chun, Y. H., \& Rainey, H. G. (2005). Goal Ambiguity and Organizational Performance in U.S. Federal Agencies. Journal of Public Administration Research and Theory, 15(4), pp. $529-557$.

Columbia Gazetteer of the World Online. (2014). Retrieved Date Accessed, 2014 from http://www.columbiagazetteer.org.

Connerly, C. E. (1993). A survey and assessment of housing trust-funds in the United States. [Article]. Journal of the American Planning Association, 59(3), pp. 306-319. doi:10.1080/01944369308975882 Retrieved from $<$ Go to ISI>://WOS:A1993LP01500004

Data-Planet Statistical Datasets. (2012). State and Local Government Finances: Tax Revenue [Data set]. Retrieved October 20, 2014, from http://www.data-planet.com/

Dillman, D. A. (2009). Mail and internet surveys: the tailored design method (3rd ed.) Hoboken, NJ: John Wiley \& Sons.

Freddie Mac. (2018). How big a difference do restricted rents make? Retrieved Date Accessed, 2018 from https://mf.freddiemac.com/research/insight/20181603-restricted-rents.html. Gallup. (2013). State of the States [Data set]. Retrieved October 20, 2014, from http://www.gallup.com/poll/125066/state-states.aspx

Geolytics. (No Date). Neighborhood Change Database [Data set]. Retrieved 2014, from http://geolytics.com

Hilbe, J. M. (2011). Negative Binomial Regression New York: Cambridge University Press. Illinois Housing Authorities Act, § 310 ILCS 10/8.2 (2008). 
Iowa Municipal Housing Projects, § 403A.12 (2017).

Joint Center for Housing Studies. (2018) The State of the Nation's Housing. Cambridge, MA: Harvard University.

Kleit, R., Garshick, \& Page, S., B. (2008). Public Housing Authorities Under Devolution. Journal of the American Planning Association, 74(1), pp. 34-44. doi:10.1080/01944360701825924

Kleit, R. G. (Forthcoming). Public housing authorities as social enterprises? Handbook of Housing: Routledge.

Kleit, R. G., \& Page, S. B. (2008). Public housing authorities under devolution. Journal of the American Planning Association, 74(1), pp. 34-44.

Kleit, R. G., \& Page, S. B. (2015). The changing role of public housing authorities in the affordable housing delivery system. Housing Studies, 30(4), pp. 621-644. doi:10.1080/02673037.2014.953919 Retrieved from http://dx.doi.org/10.1080/02673037.2014.953919

Landis, J. D., \& McClure, K. (2010). Rethinking Federal Housing Policy. Journal of the American Planning Association, 76(3), pp. 319-348. doi:10.1080/01944363.2010.484793 Retrieved from $<$ Go to ISI $>$ ://WOS:000279209500004

Lucio, J., \& De la Cruz, E. R. (2012). Affordable housing networks: a case study of the Phoenix metropolitan region. Housing Policy Debate, 22(2), pp. 219-240.

Meyers, M. K., Riccucci, N. M., \& Lurie, I. (2001). Achieving goal congruence in complex environments: The case of welfare reform. Journal of Public Administration Research and Theory, 11(2), pp. 165-202. 
Moore, M. (1995). Creating Public Value: Strategic Management in Government Cambridge, MA: Harvard University Press.

Mueller, E. J., \& Schwartz, A. (2008). Reversing the tide: will state and local governments house the poor as federal direct subsidies decline? Journal of the American Planning Association, 74(1), pp. 122-135.

National Center for Charitable Statistics. (No Date). 2008 Master File. Retrieved Date Accessed, 2012 from http://nccsweb.urban.org/PubApps/showDD.php\#Business\%20Master\%20File.

National Housing Preservation Database. (2014). [Data set]. Retrieved October, 20, 2014, from http://www.preservationdatabase.org/

National Low Income Housing Coalition. (2015). State and city funded rental housing programs. Retrieved Date Accessed, 2015 from http://nlihc.org/rental-programs/search/rentalassistance.

Nguyen, M. T., Rohe, W. M., \& Cowan, S. M. (2012). Entrenched hybridity in public housing agencies in the USA. Housing Studies, 27(4), pp. 457-475. Retrieved from http://dx.doi.org/10.1080/02673037.2012.677998

Oklahoma Public Health and Safety, § 63-1061(b) (2017).

Provan, K. G., \& Milward, H. B. (2001). Do networks really work? A framework for evaluating public sector organizational networks. Public Administration Review, 61(4), pp. 414423.

Quercia, R. G., \& Galster, G. C. (1997). The challenges facing public housing authorities in a brave new world. Housing Policy Debate, 8(3), pp. 535-569. Retrieved from http://www.fanniemaefoundation.org/programs/hpd/pdf/hpd 0803 quercia.pdf 
Reese, L. A., \& Malmer, A. B. (1994). The effects of state enabling legislation on local economic development policies. Urban Affairs Review, 30(1), pp. 114-135.

Reid, C. K. (2017). Lessons for the Future of Public Housing: Assessing the Early Implementation of the Rental Assistance Demonstration Program. Berkeley, CA: http://ternercenter.berkeley.edu/uploads/rad report.pdf

Scally, C. P. (2012). The past and future of housing policy innovation: the case of U.S. state housing trust funds Housing Studies, 27(1), pp. 127-150.

Sharp, E. B. (2005). Cities and subcultures - Exploring validity and predicting connections. [Article]. Urban Affairs Review, 41(2), pp. 132-156. doi:10.1177/1078087405279941 Retrieved from $<$ Go to ISI $>$ :/WOS:000232530200002

Stegman, M. A., \& Holden, D. (1987). Nonfederal housing programs: How states and localities are responding to federal cutbacks in low-income housing. Washington, DC

U.S. Census Bureau. (2010). American Community Survey 5-Year Estimates, 2005-2010 [Data set]. Retrieved March 25, 2015, from http://factfinder2.census.gov

U.S. Department of Housing and Urban Development. (2011). Consolidated Planning/CHAS data. Retrieved Date Accessed, 2014 from https://www.huduser.gov/portal/datasets/cp.html.

U.S. Department of Housing and Urban Development. (2014a). Choice Neighborhoods. Retrieved Date Accessed, 2015 from https://portal.hud.gov/hudportal/HUD?src=/program offices/public indian housing/prog $\underline{\mathrm{rams} / \mathrm{ph} / \mathrm{cn}}$.

U.S. Department of Housing and Urban Development. (2014b). Moving to Work--Participating Sites. Retrieved Date Accessed, 2015 from 
https://portal.hud.gov/hudportal/HUD?src=/program_offices/public indian housing/prog rams $/ \mathrm{ph} / \mathrm{mtw} / \mathrm{mtwsites}$.

U.S. Department of Housing and Urban Development. (2014c). Tour EZ/RC/ECs by State.

Retrieved Date Accessed, 2015 from

https://portal.hud.gov/hudportal/HUD?src=/program offices/comm planning/economicd evelopment/programs/rc/tour.

U.S. Department of Housing and Urban Development. (n.d.). Assisted Housing: National and Local. Retrieved Date Accessed, 2014 from https://www.huduser.gov/portal/datasets/assthsg.html.

U.S. Elections Project. (2012). Voter turnout [Data set]. Retrieved October 20, 2014, from http://www.electproject.org/home/voter-turnout/voter-turnout-data

Vale, L. J. (2017) Cities of Stars: Urban Renewal, HOPE VI, and the Changing Constellations of Poverty Governance. Paper presented at the Annual Meeting of the Association of Collegiate Schools of Planning (ACSP), Denver, CO.

Watson, N. E., Steffen, B. L., Martin, M., \& Vandenbrouke, D. A. (2017). Worst Case Housing Need 2017 Report to Congress. Washington, DC: https://www.huduser.gov/portal/sites/default/files/pdf/Worst-Case-Housing-Needs.pdf

Yerena, A. (2015). The impact of advocacy organizations on low-income housing policy in U.S. cities. Urban Affairs Review, 51(2), pp. 1-28.

\section{Appendix: Sampling Method}

To create a complete list of PHAs nationally, we began with HUD's 2009-2012 Picture of Subsidized Households as the core of our dataset. While this dataset provides information about the number of public housing and voucher units that a PHA owns or manages, it does not 
provide information about programs such as Section 202, Section 811, or LIHTC housing units. Therefore, we supplemented The Picture with data from the 2014 National Housing Preservation Database (NHPD). The preservation database lists housing sites with any federal subsidy, including units that PHAs have developed using Section 8 project-based programs, LIHTC, HOME, and Rural Housing Section 515. We filtered the owner information to develop a list of all housing authorities in the NHPD, removing Indian authorities from the final list. This resulted in the addition of 151 PHAs to our dataset that do not appear in the Picture of Subsidized Households. When we queried HUD about these PHAs, we learned that these PHAs either operate independently from HUD or no longer have any vouchers or public housing.

To gain information about unsubsidized housing that PHAs might own and other programs that PHAs use to fund development, we conducted two surveys. The first survey sample consisted of 1,894 members of the Public Housing Authorities Directors Association (PHADA) representing PHAs of varying sizes. PHADA members received by email a link to a web survey asking about their development activities and sources of funding for development. We implemented the survey between December 2013 and January 2014 using the Dillman Tailored Design Method (Dillman, 2009). The director of PHADA sent an introductory e-mail to all members, briefly explaining the purpose of the research and encouraging members to participate. We distributed the survey one week later and sent two reminders in two-week increments. 462 PHAs directors responded with information on the development in which their PHAs are involved, a response rate of $24 \%$. In the process of receiving survey responses, we learned that many executive directors represent multiple PHAs. In these cases, we combined the information for all of the PHAs that they represent and considered these PHAs to be functioning as one cohesive organization. 
Because our survey response set comprised only $10 \%$ of the full PHA population, we conducted a second supplemental survey to capture more responses. We developed an e-mail list of all PHAs using publicly available contact addresses through HUD's website and sent the survey to PHAs that did not respond to or receive the first survey distribution. Additionally, we sent a condensed survey to previous respondents to ensure that our data were accurate and up-todate. This supplemental survey was implemented in May 2015 using the Dillman method described above. The supplemental survey, distributed to 3,011 PHAs, resulted in an additional 597 responses. After assessing the information available and the survey responses received, we removed 142 cases from the dataset. These cases appear to be inactive PHAs and non-profit organizations or community action agencies that operate within a different legislative environment. After removing cases and combining survey results, we had 1,059 responses out of 3,933 active PHAs, bringing the total response rate to $27 \%$. 


\begin{tabular}{|c|c|c|c|}
\hline & \multicolumn{2}{|c|}{ Public Subsidy Status } \\
\hline & & Subsidized & Unsubsidized \\
\hline \multirow{2}{*}{$\begin{array}{l}\text { Rent } \\
\text { Received } \\
\text { by } \\
\text { Landlord }\end{array}$} & $\begin{array}{l}\text { FMR \& } \\
\text { Above }\end{array}$ & $\begin{array}{l}\text { I. VOUCHERS: } \\
\text { HOUSING CHOICE, } \\
\text { STATE \& LOCAL; } \\
\text { PROJECT-BASED }\end{array}$ & II. MARKET RATE \\
\hline & $\begin{array}{l}\text { Below } \\
\text { FMR }\end{array}$ & $\begin{array}{l}\text { III. PUBLIC HOUSING, } \\
\text { HCV, LIHTC, } \\
\text { STATE \& LOCAL } \\
\text { PROGRAMS }\end{array}$ & $\begin{array}{l}\text { IV. NATURALLY } \\
\text { OCCURING } \\
\text { AFFORDABLE } \\
\text { HOUSING }\end{array}$ \\
\hline
\end{tabular}


Table 1.

Types of federally subsidized units that PHAs own or manage by survey response status

\section{All PHAs}

PHAs responding

PHAs not

\begin{tabular}{|c|c|c|c|c|c|}
\hline $\mathrm{N}$ & 3,933 & 1,059 & & 2,874 & \\
\hline PHA manages vouchers & $54 \%$ & $62 \%$ & $\wedge$ & $51 \%$ & $*$ \\
\hline \multicolumn{6}{|l|}{ Number of vouchers PHA manages } \\
\hline Minimum & 0 & 0 & & 0 & \\
\hline Maximum & 98,810 & 47,430 & & 42,200 & \\
\hline Mean & 530 & 619 & & 558 & \\
\hline Median & 50 & 116 & & 25 & \\
\hline Total & $2,086,082$ & 655,377 & & & \\
\hline PHA owns public housing & $78 \%$ & $86 \%$ & $\wedge$ & $75 \%$ & * \\
\hline \multicolumn{6}{|l|}{ Number of public housing units PHA owns } \\
\hline Minimum & 0 & 0 & & 0 & \\
\hline Maximum & 177,200 & 6,921 & & 177,200 & \\
\hline Mean & 278 & 300 & & 270 & \\
\hline Median & 70 & 105 & & 58 & \\
\hline Total & $1,093,995$ & 317,621 & & & \\
\hline \multirow{2}{*}{$\begin{array}{l}\text { PHA manages vouchers but does not own public housing } \\
\text { PHA owns public housing but does not manage } \\
\text { vouchers }\end{array}$} & $18 \%$ & $14 \%$ & $\wedge$ & $19 \%$ & $*$ \\
\hline & $41 \%$ & $38 \%$ & $\wedge$ & $43 \%$ & $*$ \\
\hline PHA manages vouchers and owns public housing & $37 \%$ & $48 \%$ & $\wedge$ & $32 \%$ & $*$ \\
\hline PHA does not manage vouchers or own public housing & $4 \%$ & $0.3 \%$ & $\wedge$ & $6 \%$ & \\
\hline
\end{tabular}

responding 
Table 2. PHAs ownership of housing outside of public housing

\begin{tabular}{|c|c|c|c|c|c|c|c|}
\hline \multirow[b]{2}{*}{ Own housing? } & & \multicolumn{2}{|c|}{$\begin{array}{l}\text { All PHAs } \\
(\mathrm{N}=3,933)\end{array}$} & \multicolumn{2}{|c|}{$\begin{array}{c}\text { PHAs } \\
\text { responding } \\
(\mathrm{n}=1,059)\end{array}$} & \multicolumn{2}{|c|}{$\begin{array}{l}\text { PHAs not } \\
\text { responding } \\
(n=2,874)\end{array}$} \\
\hline & & 919 & $23 \%$ & 464 & $44 \%$ & 455 & $16 \%$ \\
\hline \multirow{5}{*}{$\begin{array}{l}\text { Count of non-public } \\
\text { housing units }\end{array}$} & Minimum & 0 & & 0 & & 0 & \\
\hline & Maximum & 7,227 & & 7,227 & & 2,816 & \\
\hline & Mean & 49 & & 106 & & 19 & \\
\hline & Median & 0 & & 0 & & 0 & \\
\hline & Total & 150,886 & & 111,655 & & 39,231 & \\
\hline
\end{tabular}




\begin{tabular}{|c|c|c|c|c|}
\hline Concept & Measure & $\begin{array}{c}\text { Mean or } \\
\% \\
(n=1,059) \\
\end{array}$ & $\begin{array}{c}\text { Owns } \\
\text { Units } \\
(n=464)\end{array}$ & $\begin{array}{c}\text { No } \\
\text { Units } \\
(\mathbf{n}=595)\end{array}$ \\
\hline \multirow[t]{3}{*}{ Capacity } & $\begin{array}{l}\text { PHA size (HUD size category based on } \\
\text { combined count of public housing and vouchers) }\end{array}$ & 2.9 & 3.4 & 2.5 \\
\hline & PHA does not own public housing $(1=$ Yes $)$ & $14 \%$ & $11 \%$ & $16 \%$ \\
\hline & Executive compensation $(\$)$ & $\$ 76,008$ & $\$ 93,982$ & $\$ 62,095$ \\
\hline $\begin{array}{l}\text { History of } \\
\text { housing } \\
\text { innovation }\end{array}$ & $\begin{array}{l}\text { Participation in demonstration program or } \\
\text { federal grant for local improvements in housing, } \\
\text { including Moving to Work, HOPE VI, Choice } \\
\text { Neighborhoods, Moving to Opportunity, } \\
\text { Enterprise Zones and Empowerment } \\
\text { Communities Program ( } 1=\text { Yes) }\end{array}$ & $6 \%$ & $11 \%$ & $1 \%$ \\
\hline \multirow{5}{*}{$\begin{array}{l}\text { Scale of } \\
\text { service area }\end{array}$} & County PHA $(1=$ Yes $)$ & $17 \%$ & $22 \%$ & $13 \%$ \\
\hline & City-county PHA (1=Yes) & $2 \%$ & $2 \%$ & $1 \%$ \\
\hline & Multi-county PHA (1=Yes) & $2 \%$ & $2 \%$ & $2 \%$ \\
\hline & Multi-city PHA (1=Yes) & $2 \%$ & $2 \%$ & $2 \%$ \\
\hline & City/town $(1=$ Yes $)$ & $77 \%$ & $72 \%$ & $82 \%$ \\
\hline \multirow{2}{*}{$\begin{array}{l}\text { Hybridity } \\
\text { fostering } \\
\text { organizational } \\
\text { structures }\end{array}$} & $\begin{array}{l}\text { PHA has an affiliate or subsidiary organization } \\
(1=\text { Yes })\end{array}$ & $30 \%$ & $50 \%$ & $14 \%$ \\
\hline & $\begin{array}{l}\text { PHA is independent org. from local government } \\
(1=\text { Yes })\end{array}$ & $79 \%$ & $88 \%$ & $71 \%$ \\
\hline
\end{tabular}


Table 4. Organizational Attributes: State Enabling Legislation Elements Associated with Unit Ownership Outside of the Public Housing Program

\begin{tabular}{|c|c|c|c|c|c|}
\hline \multicolumn{2}{|c|}{ Enabling Legislation Topic } & $\begin{array}{l}\text { States } \\
(\#)\end{array}$ & $\begin{array}{c}\text { PHAs } \\
(\%) \\
(\mathbf{n}=1,059)\end{array}$ & $\begin{array}{l}\text { Owns } \\
\text { Units } \\
(\%) \\
(\mathbf{n}=464)\end{array}$ & $\begin{array}{l}\text { No } \\
\text { Units } \\
\left(\begin{array}{l}\text { \%) } \\
(\mathbf{n}=\mathbf{5 9 5})\end{array}\right.\end{array}$ \\
\hline $\begin{array}{l}\text { Geographic } \\
\text { scope allowed }\end{array}$ & $\begin{array}{l}\text { Consolidated (combine or cooperate } \\
\text { with other HAs) }\end{array}$ & 19 & 45 & 48 & 43 \\
\hline \multirow{2}{*}{$\begin{array}{l}\text { Allowable } \\
\text { included uses }\end{array}$} & Community facilities & 44 & 93 & 96 & 90 \\
\hline & Commercial properties & 25 & 67 & 68 & 66 \\
\hline \multirow{4}{*}{$\begin{array}{l}\text { Affiliated } \\
\text { organization } \\
\text { Commissioner } \\
\text { S }\end{array}$} & Create or work with organization & 29 & 72 & 70 & 74 \\
\hline & Affiliate can be for-profit & 22 & 59 & 55 & 63 \\
\hline & Commissioners can be compensated & 16 & 35 & 33 & 36 \\
\hline & $\begin{array}{l}\text { Commissioner can be employees or } \\
\text { officers of governing body }\end{array}$ & 14 & 34 & 33 & 35 \\
\hline Raising funds & Governing body issues bonds, not HA & 5 & 7 & 5 & 9 \\
\hline Approval & $\begin{array}{l}\text { Projects require permission from } \\
\text { governing body or hold public hearing } \\
\text { prior to undertaking project }\end{array}$ & 20 & 47 & 47 & 47 \\
\hline \multirow[t]{5}{*}{$\begin{array}{l}\text { Population } \\
\text { targets }\end{array}$} & $\begin{array}{l}\text { Allow higher or moderate income } \\
\text { residents }\end{array}$ & 27 & 62 & 65 & 59 \\
\hline & Rural preference & 19 & 43 & 43 & 43 \\
\hline & Elderly preference & 18 & 36 & 41 & 32 \\
\hline & Persons with disabilities preference & 13 & 22 & 25 & 20 \\
\hline & Veteran/military preference & 23 & 59 & 63 & 56 \\
\hline
\end{tabular}


Table 6. Other External Environment Factors

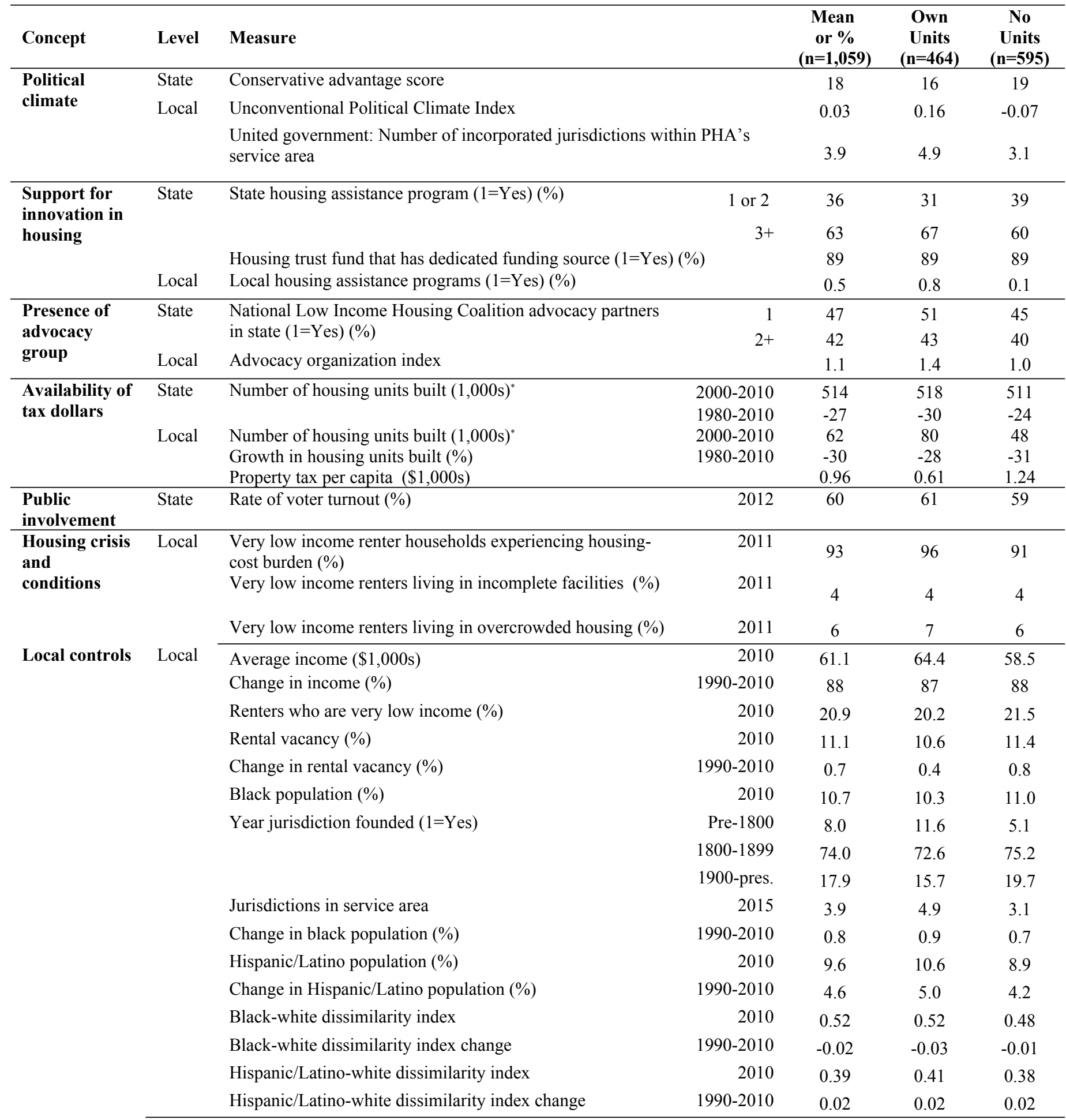


Table 6. Zero-inflated negative binomial model results (part 1) predicting PHA unit ownership outside of public housing, logistic (binary) portion predicting excess zeroes $(n=1,059)$

\begin{tabular}{|c|c|c|c|c|c|c|c|c|}
\hline Concept/Variable & $\begin{array}{r}\text { Model } 1 \\
\text { (S.E.) }\end{array}$ & & $\begin{array}{c}\text { Model } 2 \\
\text { (S.E.) }\end{array}$ & & $\begin{array}{l}\text { Model } 3 \\
\text { (S.E.) }\end{array}$ & & $\begin{array}{l}\text { Model } 4 \\
\text { (S.E.) }\end{array}$ & \\
\hline Constant & $\begin{array}{c}3.06 \\
(1.10) \\
\end{array}$ & $* *$ & $\begin{array}{c}3.76 \\
(0.83) \\
\end{array}$ & $* * *$ & $\begin{array}{c}3.65 \\
(1.02) \\
\end{array}$ & $* * *$ & $\begin{array}{c}5.21 \\
(1.24) \\
\end{array}$ & $* * *$ \\
\hline \multicolumn{9}{|l|}{ Internal characteristics } \\
\hline PHA size & $\begin{array}{l}-0.43 \\
(0.70)\end{array}$ & $* * *$ & $\begin{array}{c}0.38 \\
(0.09)\end{array}$ & $* * *$ & $\begin{array}{l}-0.44 \\
(0.10)\end{array}$ & $* * *$ & $\begin{array}{l}-0.44 \\
(0.10)\end{array}$ & $* * *$ \\
\hline PHA has no public housing & $\begin{array}{l}-1.91 \\
(0.22)\end{array}$ & $* *$ & $\begin{array}{c}1.61 \\
(0.54)\end{array}$ & $* *$ & $\begin{array}{l}-1.42 \\
(0.59)\end{array}$ & $*$ & $\begin{array}{l}-1.53 \\
(0.66)\end{array}$ & $*$ \\
\hline PHA is independent org & $\begin{array}{l}-0.75 \\
(0.34)\end{array}$ & $* * *$ & $\begin{array}{l}0.85 \\
(0.19)\end{array}$ & $* * *$ & $\begin{array}{l}-0.80 \\
(0.21)\end{array}$ & $* * *$ & $\begin{array}{l}-0.74 \\
(0.21)\end{array}$ & $* * *$ \\
\hline PHA executive compensation (scaled) & $\begin{array}{l}-0.55 \\
(0.56)\end{array}$ & & $\begin{array}{c}0.27 \\
(0.29)\end{array}$ & & $\begin{array}{l}-0.30 \\
(0.29)\end{array}$ & & $\begin{array}{l}-0.42 \\
(0.33)\end{array}$ & \\
\hline $\begin{array}{l}\text { Participated in at least } 1 \text { demonstration } \\
\text { program }\end{array}$ & $\begin{array}{l}-0.75 \\
(0.63)\end{array}$ & & $\begin{array}{c}0.48 \\
(0.49)\end{array}$ & & $\begin{array}{l}-0.61 \\
(0.53)\end{array}$ & & $\begin{array}{l}-0.66 \\
(0.53)\end{array}$ & \\
\hline PHA size*compensation & $\begin{array}{c}0.04 \\
(0.09)\end{array}$ & & $\begin{array}{c}0.04 \\
(0.07)\end{array}$ & & $\begin{array}{l}-0.01 \\
(0.07)\end{array}$ & & $\begin{array}{c}0.01 \\
(0.08)\end{array}$ & \\
\hline PHA size*PHA has no public housing & $\begin{array}{c}0.90 \\
(0.22) \\
\end{array}$ & $* * *$ & $\begin{array}{c}0.69 \\
(0.17) \\
\end{array}$ & $* * *$ & $\begin{array}{c}0.69 \\
(0.18) \\
\end{array}$ & $* * *$ & $\begin{array}{c}0.78 \\
(0.21) \\
\end{array}$ & $* * *$ \\
\hline \multicolumn{9}{|l|}{ Local environment } \\
\hline Unconventional political climate index score & $\begin{array}{l}-0.16 \\
(0.25)\end{array}$ & & $\begin{array}{c}0.32 \\
(0.21)\end{array}$ & & $\begin{array}{l}-0.29 \\
(0.23)\end{array}$ & & $\begin{array}{l}-0.14 \\
(0.24)\end{array}$ & \\
\hline Advocacy organization index & $\begin{array}{l}-0.04 \\
(0.04)\end{array}$ & & $\begin{array}{c}0.04 \\
(0.03)\end{array}$ & & $\begin{array}{c}0.01 \\
(0.03)\end{array}$ & & $\begin{array}{l}-0.03 \\
(0.04)\end{array}$ & \\
\hline Average income 2010 (scaled) & $\begin{array}{c}0.00 \\
(0.01)\end{array}$ & & $\begin{array}{c}0.01 \\
(0.01)\end{array}$ & & $\begin{array}{c}0.00 \\
(0.01)\end{array}$ & & $\begin{array}{c}0.00 \\
(0.01)\end{array}$ & \\
\hline Property tax per capita & $\begin{array}{l}-0.04 \\
(0.03)\end{array}$ & & $\begin{array}{c}0.01 \\
(0.03)\end{array}$ & & $\begin{array}{l}-0.02 \\
(0.03)\end{array}$ & & $\begin{array}{l}-0.03 \\
(0.03)\end{array}$ & \\
\hline Black-white dissimilarity index 2010 & $\begin{array}{l}-0.87 \\
(0.68)\end{array}$ & & $\begin{array}{c}0.27 \\
(0.54)\end{array}$ & & $\begin{array}{l}-0.69 \\
(0.60)\end{array}$ & & $\begin{array}{l}-0.67 \\
(0.66)\end{array}$ & \\
\hline Hispanic-white dissimilarity index 2010 & $\begin{array}{l}-0.01 \\
(0.85)\end{array}$ & & $\begin{array}{c}0.49 \\
(0.71)\end{array}$ & & $\begin{array}{c}0.44 \\
(0.76)\end{array}$ & & $\begin{array}{l}-0.13 \\
(0.81)\end{array}$ & \\
\hline $\begin{array}{l}\text { Percent very low-income renters with cost } \\
\text { burden }\end{array}$ & $\begin{array}{l}-0.95 \\
(0.11) \\
\end{array}$ & & $\begin{array}{c}0.71 \\
(0.57) \\
\end{array}$ & & $\begin{array}{l}-1.00 \\
(0.59) \\
\end{array}$ & & $\begin{array}{l}-0.86 \\
(0.61) \\
\end{array}$ & \\
\hline \multicolumn{9}{|l|}{ State environment } \\
\hline At least 1 active state capital program & - & & $\begin{array}{c}0.00 \\
(0.02)\end{array}$ & & $\begin{array}{l}-0.02 \\
(0.03)\end{array}$ & & $\begin{array}{l}-0.10 \\
(0.05)\end{array}$ & $*$ \\
\hline $\begin{array}{l}\text { Percent growth in housing units built 1980- } \\
2010\end{array}$ & - & & $\begin{array}{c}0.00 \\
(0.00)\end{array}$ & & $\begin{array}{c}0.00 \\
(0.00)\end{array}$ & & $\begin{array}{c}0.01 \\
(0.01)\end{array}$ & \\
\hline Trust fund with revenue source & - & & $\begin{array}{c}0.39 \\
(0.26)\end{array}$ & & $\begin{array}{c}-0.12 \\
(0.34)\end{array}$ & & $\begin{array}{l}-0.23 \\
(0.43)\end{array}$ & \\
\hline
\end{tabular}

Table continues 
Table 6 Continued

\begin{tabular}{|c|c|c|c|c|c|}
\hline State enabling legislation & & & & & \\
\hline Consolidated PHAs allowed & - & - & $\begin{array}{l}-0.27 \\
(0.22)\end{array}$ & $\begin{array}{l}-0.75 \\
(0.27)\end{array}$ & $* *$ \\
\hline Community facilities allowed & - & - & $\begin{array}{c}0.15 \\
(0.49)\end{array}$ & $\begin{array}{l}-0.60 \\
(0.56)\end{array}$ & \\
\hline Commercial properties allowed & - & - & $\begin{array}{c}0.04 \\
(0.25)\end{array}$ & $\begin{array}{c}0.03 \\
(0.29)\end{array}$ & \\
\hline Can create or work with org & - & - & $\begin{array}{c}0.60 \\
(0.37)\end{array}$ & $\begin{array}{c}0.24 \\
(0.42)\end{array}$ & \\
\hline Affiliate organization can be for-profit & - & - & $\begin{array}{c}0.39 \\
(0.36)\end{array}$ & $\begin{array}{c}0.38 \\
(0.45)\end{array}$ & \\
\hline Commissioners can be compensated & - & - & $\begin{array}{c}0.21 \\
(0.23)\end{array}$ & $\begin{array}{c}0.36 \\
(0.26)\end{array}$ & \\
\hline $\begin{array}{l}\text { Commissioners can be employees of } \\
\text { jurisdiction }\end{array}$ & - & - & $\begin{array}{l}-0.11 \\
(0.24)\end{array}$ & $\begin{array}{c}0.49 \\
(0.33)\end{array}$ & \\
\hline Governing body issues bonds & - & - & $\begin{array}{c}0.20 \\
(0.35)\end{array}$ & $\begin{array}{l}-1.21 \\
(0.49)\end{array}$ & $*$ \\
\hline Project requires aproval & - & - & $\begin{array}{c}0.21 \\
(0.20)\end{array}$ & $\begin{array}{c}0.02 \\
(0.26)\end{array}$ & \\
\hline Allow higher-income residents & - & - & $\begin{array}{l}-0.66 \\
(0.23)\end{array}$ & $\begin{array}{l}-0.25 \\
(0.29)\end{array}$ & \\
\hline Rural preference & - & - & $\begin{array}{l}-0.37 \\
(0.26)\end{array}$ & $\begin{array}{l}-0.58 \\
(0.42)\end{array}$ & \\
\hline Elderly preference & - & - & $\begin{array}{l}-0.54 \\
(0.27)\end{array}$ & $\begin{array}{l}-0.32 \\
(0.33)\end{array}$ & \\
\hline Persons with disabilities preference & - & - & $\begin{array}{l}-0.19 \\
(0.33)\end{array}$ & $\begin{array}{c}0.00 \\
(0.44)\end{array}$ & \\
\hline Veteran/military preference & - & - & $\begin{array}{l}-0.23 \\
(0.19)\end{array}$ & $\begin{array}{c}-0.44 \\
(0.25) \\
\end{array}$ & \\
\hline \multicolumn{6}{|l|}{ HUD Regions $^{\mathbf{a}}$} \\
\hline New England & - & - & - & $\begin{array}{c}0.29 \\
(0.74)\end{array}$ & \\
\hline New York-New Jersey & - & - & - & $\begin{array}{c}0.74 \\
(0.67)\end{array}$ & \\
\hline Mid-Atlantic & - & - & - & $\begin{array}{l}-0.44 \\
(0.42)\end{array}$ & \\
\hline Southeastern & - & - & - & $\begin{array}{c}0.61 \\
(0.40)\end{array}$ & \\
\hline Midwest & - & - & - & $\begin{array}{l}-1.10 \\
(0.56)\end{array}$ & $*$ \\
\hline Plains States & - & - & - & $\begin{array}{c}-0.07 \\
(0.50)\end{array}$ & \\
\hline West & - & - & - & $\begin{array}{c}-2.93 \\
(0.55)\end{array}$ & $* * *$ \\
\hline Southwest & - & - & - & $\begin{array}{c}1.05 \\
(1.01)\end{array}$ & \\
\hline Northwest & - & - & - & $\begin{array}{c}-2.13 \\
(1.01) \\
\end{array}$ & $*$ \\
\hline Log Likelihood & $-3,182$ & $-3,278$ & $-3,242$ & $-3,205$ & \\
\hline Degrees of Freedom & 153 & 73 & 102 & 120 & \\
\hline Vuong $z$ & 11.7 & 10.4 & 10.2 & 11.9 & \\
\hline Prob. $>z$ & 0.00 & 0.00 & 0.00 & 0.00 & \\
\hline AIC & 6,670 & 6,701 & 6,688 & 6,649 & \\
\hline
\end{tabular}


Table 7. Zero-inflated negative binomial model results (Part 2)

predicting PHA unit ownership outside public housing

negative binomial (continuous) portion of the modelling $(n=464)$

\begin{tabular}{|c|c|c|c|c|c|c|c|c|}
\hline & Model 1 & & Model 2 & & Model 3 & & Model 4 & \\
\hline Concept/Variable & (S.E.) & & (S.E.) & & (S.E.) & & (S.E.) & \\
\hline Constant & $\begin{array}{c}0.70 \\
(1.36)\end{array}$ & & $\begin{array}{c}1.43 \\
(1.47)\end{array}$ & & $\begin{array}{c}1.38 \\
(1.53)\end{array}$ & & $\begin{array}{c}0.21 \\
(1.95)\end{array}$ & \\
\hline \multicolumn{9}{|l|}{ Internal characteristics } \\
\hline PHA is independent org & $\begin{array}{c}0.26 \\
(0.21)\end{array}$ & & $\begin{array}{c}0.25 \\
(0.23)\end{array}$ & & $\begin{array}{c}0.29 \\
(0.21)\end{array}$ & & $\begin{array}{c}0.26 \\
(0.22)\end{array}$ & \\
\hline PHA has no public housing & $\begin{array}{l}-1.02 \\
(0.52)\end{array}$ & & $\begin{array}{c}0.04 \\
(0.47)\end{array}$ & & $\begin{array}{l}-0.78 \\
(0.52)\end{array}$ & & $\begin{array}{l}-0.62 \\
(0.53)\end{array}$ & \\
\hline PHA size category & $\begin{array}{c}0.17 \\
(0.08)\end{array}$ & $*$ & $\begin{array}{c}0.33 \\
(0.08)\end{array}$ & $* * *$ & $\begin{array}{c}0.22 \\
(0.08)\end{array}$ & $* *$ & $\begin{array}{c}0.20 \\
(0.07)\end{array}$ & $* *$ \\
\hline PHA executive compensation (scaled) & $\begin{array}{c}0.11 \\
(0.21)\end{array}$ & & $\begin{array}{c}0.23 \\
(0.21)\end{array}$ & & $\begin{array}{c}0.11 \\
(0.22)\end{array}$ & & $\begin{array}{c}0.16 \\
(0.21)\end{array}$ & \\
\hline Participated in at least 1 demonstration program & $\begin{array}{l}-0.11 \\
(0.21)\end{array}$ & & $\begin{array}{c}0.34 \\
(0.25)\end{array}$ & & $\begin{array}{l}-0.21 \\
(0.22)\end{array}$ & & $\begin{array}{l}-0.16 \\
(0.21)\end{array}$ & \\
\hline Affiliate org develops/owns housing & $\begin{array}{c}0.19 \\
(0.14)\end{array}$ & & $\begin{array}{c}0.09 \\
(0.13)\end{array}$ & & $\begin{array}{c}0.07 \\
(0.13)\end{array}$ & & $\begin{array}{c}0.11 \\
(0.13)\end{array}$ & \\
\hline County $\mathrm{PHA}^{\mathrm{a}}$ & $\begin{array}{c}0.37 \\
(0.21)\end{array}$ & . & $\begin{array}{c}0.20 \\
(0.19)\end{array}$ & & $\begin{array}{c}0.16 \\
(0.20)\end{array}$ & & $\begin{array}{c}0.26 \\
(0.20)\end{array}$ & \\
\hline City-County $\mathrm{PHA}^{\mathrm{a}}$ & $\begin{array}{c}0.11 \\
(0.29)\end{array}$ & & $\begin{array}{c}0.04 \\
(0.33)\end{array}$ & & $\begin{array}{c}0.25 \\
(0.36)\end{array}$ & & $\begin{array}{c}0.29 \\
(0.32)\end{array}$ & \\
\hline Multi-county $\mathrm{PHA}^{\mathrm{a}}$ & $\begin{array}{c}0.98 \\
(0.48)\end{array}$ & $*$ & $\begin{array}{c}0.61 \\
(0.43)\end{array}$ & & $\begin{array}{c}0.88 \\
(0.51)\end{array}$ & & $\begin{array}{c}0.82 \\
(0.46)\end{array}$ & \\
\hline Multi-city PHA ${ }^{\mathrm{a}}$ & $\begin{array}{l}-0.35 \\
(0.32)\end{array}$ & & $\begin{array}{c}0.22 \\
(0.34)\end{array}$ & & $\begin{array}{l}-0.48 \\
(0.32)\end{array}$ & & $\begin{array}{l}-0.36 \\
(0.33)\end{array}$ & \\
\hline PHA size*compensation & $\begin{array}{c}0.07 \\
(0.05)\end{array}$ & & $\begin{array}{c}0.04 \\
(0.05)\end{array}$ & & $\begin{array}{c}0.07 \\
(0.05)\end{array}$ & & $\begin{array}{c}0.07 \\
(0.05)\end{array}$ & \\
\hline PHA has no public housing*PHA size & $\begin{array}{c}0.51 \\
(0.16)\end{array}$ & $* *$ & $\begin{array}{c}0.20 \\
(0.16)\end{array}$ & & $\begin{array}{c}0.40 \\
(0.16)\end{array}$ & $*$ & $\begin{array}{c}0.37 \\
(0.16)\end{array}$ & * \\
\hline \multicolumn{9}{|l|}{ Local environment } \\
\hline Unconventional Political Climate Index score & $\begin{array}{c}0.43 \\
(0.17)\end{array}$ & * & $\begin{array}{c}0.24 \\
(0.16)\end{array}$ & & $\begin{array}{c}0.41 \\
(0.16)\end{array}$ & $*$ & $\begin{array}{c}0.44 \\
(0.17)\end{array}$ & $* *$ \\
\hline Advocacy organization index & $\begin{array}{c}0.01 \\
(0.01)\end{array}$ & & $\begin{array}{l}0.000 \\
(0.01)\end{array}$ & & $\begin{array}{l}0.004 \\
(0.01)\end{array}$ & & $\begin{array}{l}0.004 \\
(0.01)\end{array}$ & \\
\hline Average income 2010 (scaled) & $\begin{array}{c}0.21 \\
(0.31)\end{array}$ & & $\begin{array}{c}0.57 \\
(0.51)\end{array}$ & & $\begin{array}{c}0.33 \\
(0.38)\end{array}$ & & $\begin{array}{c}0.36 \\
(0.37)\end{array}$ & \\
\hline Property tax per capita & $\begin{array}{l}-0.04 \\
(0.03)\end{array}$ & & $\begin{array}{c}0.03 \\
(0.02)\end{array}$ & & $\begin{array}{l}-0.05 \\
(0.02)\end{array}$ & & $\begin{array}{r}*-0.04 \\
(0.03)\end{array}$ & \\
\hline Black-white dissimilarity index 2010 & $\begin{array}{l}-0.00 \\
(0.00)\end{array}$ & & $\begin{array}{c}0.01 \\
(0.00)\end{array}$ & $* *$ & $\begin{array}{l}-0.00 \\
(0.00)\end{array}$ & & $\begin{array}{l}-0.01 \\
(0.00)\end{array}$ & \\
\hline Hispanic-white dissimilarity index 2010 & $\begin{array}{l}-0.04 \\
(0.11)\end{array}$ & & $\begin{array}{c}0.16 \\
(0.11)\end{array}$ & & $\begin{array}{l}-0.08 \\
(0.11)\end{array}$ & & $\begin{array}{l}-0.14 \\
(0.11)\end{array}$ & \\
\hline Percent very low-income renters with cost burden & $\begin{array}{l}0.003 \\
(0.03)\end{array}$ & & $\begin{array}{c}0.03 \\
(0.03)\end{array}$ & & $\begin{array}{l}0.001 \\
(0.03)\end{array}$ & & $\begin{array}{l}0.002 \\
(0.03)\end{array}$ & \\
\hline $\begin{array}{l}\text { Percent very low-income renters with incomplete } \\
\text { facilities }\end{array}$ & $\begin{array}{l}-1.15 \\
(1.38)\end{array}$ & & $\begin{array}{c}0.54 \\
(1.44)\end{array}$ & & $\begin{array}{l}-0.97 \\
(1.25)\end{array}$ & & $\begin{array}{l}-1.13 \\
(1.29)\end{array}$ & \\
\hline Percent very low-income renters with overcrowding & $\begin{array}{c}2.11 \\
(0.94)\end{array}$ & * & $\begin{array}{c}2.31 \\
(0.98)\end{array}$ & $*$ & $\begin{array}{c}2.54 \\
(0.92)\end{array}$ & $* *$ & $\begin{array}{c}2.26 \\
(0.94)\end{array}$ & $*$ \\
\hline Percent of renters that are very low-income & $\begin{array}{c}0.02 \\
(0.01)\end{array}$ & & $\begin{array}{c}0.01 \\
(0.01)\end{array}$ & & $\begin{array}{c}0.01 \\
(0.01)\end{array}$ & & $\begin{array}{c}0.02 \\
(0.01)\end{array}$ & \\
\hline Percentage point change in rental vacancy $1990-2010$ & $\begin{array}{l}-0.01 \\
(0.04)\end{array}$ & & $\begin{array}{c}0.01 \\
(0.03)\end{array}$ & & $\begin{array}{l}-0.02 \\
(0.04)\end{array}$ & & $\begin{array}{l}-0.02 \\
(0.04)\end{array}$ & \\
\hline Percent rental vacancy 2010 & $\begin{array}{c}0.01 \\
(0.02)\end{array}$ & & $\begin{array}{c}0.00 \\
(0.02)\end{array}$ & & $\begin{array}{c}0.01 \\
(0.02)\end{array}$ & & $\begin{array}{c}0.01 \\
(0.02)\end{array}$ & \\
\hline
\end{tabular}


Table 7 continued

Concept/Variable

Percent change in average income 1990-2010

Average income 2010 (scaled)

Jurisdiction founded before 1800

Jurisdiction founded 1800-1899

Number of incorporated jurisdictions in service area

Percentage point change in black population 1990-2010

Percent black population 2010

Percentage point change in Hispanic population 19902010

Percent Hispanic population 2010

Black-white dissimilarity index change 1990-2010

Black-white dissimilarity index 2010

Hispanic-white dissimilarity index change 1990-2010

Hispanic-white dissimilarity index 2010

Housing growth*units built

Rental vacancy change* rental vacancy

Average income change*average income

Black population change*black population share

Hispanic population change*Hispanic population share

Black-white dissimilarity index change*black-white dissimilarity index

Hispanic-white dissimilarity index change*Hispanicwhite dissimilarity index

Percent very low-income renters with incomplete facilities
Model 1

(S.E.)

0.01

(0.01)

$-0.36$

(0.69)

$-0.09$

$(0.25)$

0.16

(0.17)

0.01

$(0.01)$

0.24

$(0.07)$

$-0.01$

$(0.01)$

0.04

$(0.04)$

0.0004

$(0.02)$

$-0.49$

(0.97)

1.03

(0.65)

2.55

(1.84)

$-0.37$

(0.86)

$-0.002$

(0.00)

0.001

$(0.00)$

0.002

(0.01)

$-0.00$

$(0.00)$

$-0.00$

$(0.00)$

$-2.30$

(2.06)

$-5.47$

(3.19)

$-1.15$

(1.38)
Model 2

(S.E.)

0.01
$(0.01)$

0.62

(0.52)

0.04

(0.25)

0.24

(0.19)

0.00

(0.01)

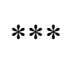

0.19

(0.07)

0.01

(0.01)

0.04

(0.04)

0.01

(0.01)

0.17

(0.63)

0.94

(0.60)

3.88

(1.46)

0.49

(0.71)

0.003

$(0.00)$

0.001

(0.00)

0.01

(0.01)

** $\quad 0.00$

(0.00)

0.00

(0.00)

2.73

(1.58)

7.13

(2.34)

0.54

(1.44)

\begin{tabular}{lccc}
- & 0.01 & -0.004 & -0.01 \\
& $(0.01)$ & $(0.01)$ & $(0.02)$ \\
- & 0.04 & -0.65 & -0.80 \\
& $(0.03)$ & $(0.63)$ & $(0.67)$ \\
- & 0.24 & -0.72 & -0.98 \\
& $(0.27)$ & $(0.61)$ & $(0.76)$ \\
- & 0.42 & 0.68 & 1.27 \\
- & $(0.30)$ & $(0.38)$ & $(0.54)$ \\
& 0.46 & $*-0.01$ & -0.38 \\
& $(0.23)$ & $(0.27)$ & $(0.31)$ \\
\hline
\end{tabular}

(S.E.)

0.01

(0.01)

$-0.14$

(0.60)

$-0.18$

(0.26)

0.10

(0.18)

0.00

(0.01)

0.19

(0.06)

$-0.01$

(0.01)

0.04

(0.04)

0.01

(0.02)

$-0.51$

(0.85)

1.37

(0.69)

3.21

(1.64)

$-0.81$

(0.87)

$-0.003$

$(0.00)$

0.003

(0.00)

0.001

$(0.01)$

$-0.00$

(0.00)

0.00

(0.00)

$-1.89$

(1.74)

$-5.30$

(2.87)

$-1.13$

(1.29)

-0.97
$(1.25)$

(0.31) 
2 or more NLIHC state partners

Housing units built 2000-2010 (scaled)

Percent growth in housing units built 1980-2010

Percent voter turnout 2012

Housing growth*state units built

\section{State Enabling legislation}

Consolidated PHAs allowed

Community facilities allowed

Commercial properties allowed

Can create or work with org

Affiliate organization can be for-profit

Commissioners can be compensated

Commissioners can be employees of jurisdiction

Governing body issues bonds

Project requires approval

Allow higher-income residents

Rural preference

Elderly preference

Persons with disabilities preference

Veteran/military preference

$\begin{array}{lccc}- & 0.19 & 0.17 & 0.10 \\ & (0.25) & (0.25) & (0.28) \\ - & 0.03 & 0.0002 & -0.16 \\ & (0.17) & (0.24) & (0.33) \\ - & 0.01 & .0 .004 & -0.001 \\ & (0.01) & (0.01) & (0.01) \\ - & 0.02 & -0.01 & 0.01 \\ & (0.01) & (0.02) & (0.02) \\ - & 0.01 & 0.004 & -0.001 \\ & (0.01) & (0.01) & (0.01)\end{array}$

$-$

$-\quad-10$.

$-0.03$

$(0.22)$

0.53

(0.44)

0.20

$(0.22)$

0.59

(0.40)

$-0.82$

(0.34)

$-0.03$

$(0.21)$

$-0.27$

$(0.21)$

$-0.37$

$(0.29)$

0.32

$(0.21)$

$-0.02$

$(0.20)$

0.24

(0.20)

$-0.16$

$(0.20)$

0.22

$(0.31)$

0.11

$(0.23)$
0.08

$(0.29)$

0.78

$(0.51)$

0.33

$(0.25)$

0.56

(0.47)

$-0.86$

(0.36)

$-0.10$

$(0.23)$

$-0.49$

$(0.26)$

$-0.79$

(0.40)

0.01

(0.23)

$-0.17$

(0.29)

0.43

$(0.23)$

$-0.50$

(0.29)

0.15

(0.44)

0.01

(0.25)

\section{HUD Regions ${ }^{a}$}

New England $-0.59$ $(0.82)$

New York-New Jersey

Mid-Atlantic $-0.41$

$(0.79)$

$-1.27$

$(0.51)$

Southeastern

Midwest

Plains States

$-0.89$

(0.41)

$-0.38$

(0.56)

0.29

(0.51)

$-0.43$

(0.47)

Southwest 


\begin{tabular}{|c|c|c|c|c|c|c|}
\hline Theta & $\begin{array}{l}-0.13 \\
(0.07)\end{array}$ & $\begin{array}{l}-0.27 \\
(0.07)\end{array}$ & $* * *$ & $\begin{array}{l}-0.21 \\
(0.07)\end{array}$ & $* *$ & $\begin{array}{l}-0.18 \\
(0.07)\end{array}$ \\
\hline Log Likelihood & $-3,182$ & $\begin{array}{c}- \\
3,278\end{array}$ & & $-3,242$ & & $-3,205$ \\
\hline Degrees of Freedom & 153 & 73 & & 102 & & 120 \\
\hline Vuong $Z$ & 11.7 & 10.4 & & 10.2 & & 11.9 \\
\hline Prob. $>Z$ & 0.00 & 0.00 & & 0.00 & & 0.00 \\
\hline $\mathrm{AIC}$ & 6,670 & 6,701 & & 6,688 & & 6,649 \\
\hline
\end{tabular}

Note: Model 1 includes state fixed effects; Model 2 and 3 omit them. Model 3 includes HUD Region fixed effects but not shown. ${ }^{*} \mathrm{p}<0.10,{ }^{* *} \mathrm{p}<0.05,{ }^{* * *} \mathrm{p}<0.01$

${ }^{a}$ Reference category is city service area. 